\title{
Association of trace elements with oral submucous fibrosis.
}

1. BDS, MDS Oral Pathology Associate Professor Oral Pathology Isra Dental College Isra University Hyderabad,Sindh 2. BDS, M.Sc

Assistant Professor Oral Pathology Bhitai Dental and Medical College Mirpurkhas.

3. BDS, M.Sc

Assistant Professor Oral Pathology Bibi Aseefa Dental (SMBBMU) College Larkana-Pakistan

4. MBBS, DCP, M.Phil

Lecturer Pathology LUMHS Jamshoro.

5. BDS, M.Sc Oral Pathology Assistant Professor Oral Pathology Bhitai Dental \& Medical College Mirpurkhas.

6. BDS, M.Sc (Periodontology) Assistant Professor Periodontology Isra Dental College, Isra University, Hyderabad.

Correspondence Address:

Dr. Waqas Iqbal

Associate Professor (Oral Pathology)

Isra University Hyderabad.

waqasiqbalhere@gmail.com

Article received on:

21/09/2020

Accepted for publication:

$14 / 12 / 2020$
Waqas Iqbal', Arhama Surwaich ${ }^{2}$, Surwaich Ali Channa ${ }^{3}$, Khalid Yousuf ${ }^{4}$, Shahzaman Memon ${ }^{5}$, Shafquat Hussain Khuwaja ${ }^{6}$

ABSTRACT... Objectives: Clinical assessment of OSMF patients visiting Isra dental college Hyderabad Sindh and correlation of trace elements in OSMF pathogenesis. Study Design: Observational Study. Setting: Outpatient Department, Oral Surgery Isra Dental College Hyderabad Sindh. Period: February 2016 January 2017. Material \& Methods: Sixty research participants were categorized into control (group-II) and experimental group (group-I). Both clinical and physiological demographics of the research participants were recorded on a predesigned questionnaire. In next phase, estimation of serum copper and serum zinc levels were determined for both control and OSMF patients by using spectrometric analysis. Patient data analysis was done by using Chi-square test and student's t test. Where Microsoft office 2010 tools were also used for data presentation. Results: Based on clinical presentation $80 \%$ patient were presenting with burning sensation in oral cavity in thirty OSMF patients. Where in control group only 3.3\% patients were facing burning sensation in oral cavity. By assessing the functional staging of oral submucosa fibrosis about $50 \%$ patients were presenting stageII OSMF cytology. Where all the thirty participants in experimental group were presenting mucosal blanching. About $36 \%$ patients suffering from OSMF were using Gutka and $33 \%$ patients were using areca nut. Serum Zn mean value estimation in controls (Group II) and cases (Group I OSMF) was noted as $68.06 \pm 17.10$ and $94.20 \pm 15.11 \mu \mathrm{g} / \mathrm{dl}$ respectively $(\mathrm{t}=6.27$, $\mathrm{p}=0.001)$. Conclusion: The present study concludes that increased serum trace element levels has significant correlation in the development and progression of OSMF.

Key words: $\quad$ LYSYL Oxidase Activity Causing, Oral Submucous Fibrosis, Sindh-Pakistan.

Article Citation: Iqbal W, Surwaich A, Channa SA, Yousuf K, Memon S, Khawaja SH. Association of trace elements with Oral Submucous Fibrosis. Professional Med J 2021; 28(8):1161-1165. https://doi.org/10.29309/TPMJ/2021.28.08.6095

\section{INTRODUCTION}

Oral submucous fibrosis (OSF) is recognized as an irreversible chronic disease impacting the mucus lining of oral, pharyngeal and esophageal cavity. The general appearance of OSF represents turgidity of affected tissues and ends up with proliferation into squamous cellular carcinomas. The major changes within oral tissues include localized systemic sclerosis. The tobacco-based products and areca nut chewing were reported as potential etiological agents of the OSF yet. ${ }^{1}$ Many young people in the community are consuming the areca nut which precipitates the OSMF condition. ${ }^{2}$ Areca nut alkaloids stimulate the proliferation of fibroblast within oral submucosa and increase the collagen synthesis. Areca nut contains alkaloids like tannins and arecoline which are the potent stimulators of fibroblast proliferation. Overuse of areca nut particularly night quid are reported as stimulator of malignant growths. Duration and frequency of areca nut chewing is directly related to the OSMF progression. ${ }^{3}$ Areca nut is also reported to contain traces of elements- the zinc, magnesium, copper and iron. Severity of OSMF is related with the trace elements levels and the stage of disease has a definite relationship. Increased copper concentration in certain areca nut mix has been reported as a possible risk of OSMF in predisposed people. ${ }^{4}$ Salivary copper is raised in areca nut users. Elevated salivary copper stimulates the activity of lysyl oxidase enzyme which is copper dependent enzyme. The lysyl oxidase is fibrogenic as it stimulates the fibroblasts in the presence of copper. This is 
how the copper plays role in the pathogenesis of OSMF. ${ }^{5-7}$ Another mechanism of stimulated fibrogenesis is through the mutagenesis of P53 aberrations. Aberrations of P53 plays potentially significant role in the induction of oncogenesis of oral squamous cell carcinoma. Thus, the serum copper levels are directly proportional to the grade and severity of OSMF in areca nut chewers. ${ }^{4}$ The subjected study aims to assess the correlation of trace elements with oral submucous fibrosis among patients enrolled from Sindh Pakistan.

\section{MATERIAL \& METHODS}

Current observational study was conducted on patients of oral submucosal fibrosis (OSMF) attending the Outpatient Department, Oral Surgery Isra Dental College Hyderabad Sindh during January-2016 to December 2017.

By following random model analysis at $95 \%$ confidence interval and Solvin's formula, patient sample size was determined. The study was approved by Isra University, Dental College ethical committee (IURR-10 /AQK/BASR/24/2016/1310) and written informed consent was obtained prior to study. In very first phase of the subjected research study, research participants were equally categorized into group- I (control group participant) and group-II (experimental group participants).

Similarly, participants from each group were presented with a questionnaire for complete data acquisition including patient demographic details and disease history. Once patient clinical assessment was made. The patient specific clinical parameters include, functional staging, mucosal blanching, tongue movement and pain sensation in general. In next phase estimation of serum copper and zinc was achieved by following standard blood collection and serum isolation method. The $6 \mathrm{ml}$ blood sample was collected in gel tube and then we centrifuged at 3000 rpm gravity for $10 \mathrm{~min}$ to separate the serum from blood. The 4 to $5 \mathrm{ml}$ serum collected in this way was analyzed by spectrophotometric method on Hitachi 902(Roche Germany). The levels of copper and zinc were estimated from serum samples of both groups. Patient data analysis was done by Chi-square test and student's test was employed for mean values determination.

\section{RESULTS}

In current observational research study equal number of participants were placed in control group (Group-I) and experimental group (GroupII), each group participants were tested for clinical and biochemical analysis. Based on clinical presentation, only $3.3 \%$ patients complained of burning sensation within oral cavity in control group participants. Where in participant's group $80 \%$ patient were suffering from burning sensation. The symptomatic difference between each group participant was found statistically significant $(p=0.0001)$ and chi square value $\left(X^{2}=\right.$ 30), Table-I.

Enlightening functional staging of experimental and control group participants represents that, most of patients in OSMF group (Group-I) represent stage-II and stage-III oral submucous fibrosis. The functional staging was done to assess the severity of disease and interventions in the routine physiology. In control group participants only, limited cases were presenting oral submucous fibrosis in control group healthy participants. The healthy participants representing $96.6 \%$ functional staging-I outcomes ends up without further progression suggested normal regulation of trace elements and their content $(p=0.033)\left(X^{2}=30\right)$ as mentioned in Table-II.

Discussing, the mucosal blanching, $0 \%(n=0)$ controls group participants were found. In contrast to control group participants $100 \%(n=30)$ cases were presenting mucosal blanching in OSMF participants group. The mucosal blanching was assessed on the behalf of patient clinical characterization. As patients were presenting mixed inflammatory edema, epithelial atrophy, fibroblasts and fibrous bands of mucous in oral cavity. The difference was statistically significant $P$ value $(p=0.001)$ and chi square value $\left(X^{2}=31\right)$, Table-III The tongue immobility was noted in $0 \%$ $(n=0)$ participants in control group and $73.3 \%$ $(n=22)$ in OSMF patients. While $26.6 \%(n=8)$ showed no tongue immobility. The difference was statistically significant $P$ value $(p=0.0001)$ and 
chi square value $\left(X^{2}=33\right)$, Table-III.

The assessment of type of areca nut consumption include, Sweet scented areca nut, Manipuri and Gutkha were noted in 10 (33.3\%), 15 (50\%) and 11 (36.6\%) in both group participants respectively. Results showed that, most of the patients were using Manipuri and least was the sweet-scented areca with $P$-value $(p=0.0001)$ and chi square value $\left(X^{2}=29\right)(d f=29)$.

In next phase of the subjected research study, Serum $\mathrm{Cu}$ and serum $\mathrm{Zn}$ levels were calculated, serum Cu mean \pm SD in controls (Group II) and cases (Group I OSMF) was noted as $114.0 \pm 13.8$ and $86 \pm 4.20 \mu \mathrm{g} / \mathrm{dl}$ respectively $(\mathrm{p}=0.0001)$.

The estimation of Serum $\mathrm{Zn}$ mean $\pm \mathrm{SD}$ in controls (Group II) and cases (Group I OSMF) was noted as $68.06 \pm 17.10$ and $94.20 \pm 15.11$ $\mu \mathrm{g} / \mathrm{dl}$ respectively $(\mathrm{t}=6.27, \mathrm{p}=0.001)$ Table-VI.

\section{DISCUSSION}

Trace element refers to the chemical elements, which are present or required in minute quantities. ${ }^{8}$ These TEs play an imperative role in numerous physiological and metabolic processes in humans. Metal ions are necessary for humans as $>25 \%$ of the enzymes need to be activated by them. ${ }^{9}$

\begin{tabular}{|c|c|c|c|c|c|}
\hline Study Groups & Yes & No & Df & $\mathbf{X}^{2}$ & P-value \\
\hline Group-I. OSMF $(n=30)$ & $24(80 \%)$ & $6(20 \%)$ & 29 & \multirow{2}{*}{30.0} & \multirow{2}{*}{0.033} \\
\hline Group-II. $(n=30)$ Controls & $1(3.3 \%)$ & $29(96.6 \%)$ & 29 & & \\
\hline
\end{tabular}

Table-I. Burning sensation in oral cavity $(n=60)$.

\begin{tabular}{|l|c|c|c|c|c|c|}
\hline \multicolumn{1}{|c|}{ Study groups } & Stage 1 & Stage 2 & Stage 3 & df & $\mathbf{X}^{2}$ & p-value \\
\hline Group I. OSMF $(n=30)$ & $7(23.3 \%)$ & $15(50 \%)$ & $8(26.6 \%)$ & 29 & 30 & 0.033 \\
\hline Group II. Controls $(n=30)$ & $29(96.6 \%)$ & $1(1.3 \%)$ & $0(0 \%)$ & 29 & &
\end{tabular}

Table-II. Functional staging $(n=60)$.

\begin{tabular}{|l|c|c|c|c|c|}
\hline \multicolumn{1}{|c|}{ Study group } & Yes & No & df & $\mathbf{X}^{2}$ & p-value \\
\hline Group II. Controls $(n=30)$ & $0(0 \%)$ & $30(100 \%)$ & 29 & 31 & 0.001 \\
\hline Group I. OSMF $(n=30)$ & $30(100 \%)$ & $0(0 \%)$ & 29 & & \\
\hline
\end{tabular}

Table-III. Mucosal blanching $(n=60)$.

\begin{tabular}{|l|c|c|c|c|c|}
\hline \multicolumn{1}{|c|}{ Study Groups } & Yes & No & df & $\mathbf{X}^{2}$ & p-value \\
\hline Group I. OSMF $(n=30)$ & $22(73.3 \%)$ & $8(26.6 \%)$ & $\mathbf{2 9}$ & 33 & 0.0001 \\
\hline Group II. Controls $(n=30)$ & $0(0 \%)$ & $30(100 \%)$ & 29 & &
\end{tabular}

Table-IV. Tongue immobility $(n=60)$.

\begin{tabular}{|l|c|c|c|c|c|c|}
\hline $\begin{array}{l}\text { Group B. OSMF } \\
(\mathbf{n = 3 0})\end{array}$ & Sweet Sented areca nut & Manipuri & Gutkha & df & $\mathbf{X}^{2}$ & p-value \\
\hline & $10(33.3 \%)$ & $15(50 \%)$ & $11(36.6 \%)$ & 29 & 29 & 0.001
\end{tabular}

Table-V. Types of areca nut consumption $(n=60)$.

\begin{tabular}{|c|c|c|c|c|c|}
\hline Study Groups & Mean & SD & df & t-value & p-value \\
\hline \multicolumn{6}{|c|}{ Group I. OSMF $(n=30)$} \\
\hline Copper Level & 86 & 4.2 & 29 & 10.6 & 0.0001 \\
\hline Zinc Level & 94.2 & 15.11 & 29 & 6.27 & 0.001 \\
\hline \multicolumn{6}{|c|}{ Group II. Controls $(n=30)$} \\
\hline Copper Level & 114 & 13.88 & 29 & 10.6 & 0.0001 \\
\hline Zinc Level & 68.06 & 17.1 & 29 & 6.27 & 0.001 \\
\hline
\end{tabular}

Table-VI. Serum copper and Zinc $(\mu \mathrm{g} / \mathrm{dl})$ of study population $(n=60)$. 
Schwartz reported the importance of TEs as resourceful anti-cancer agents, which thereby led to the discovery of new diagnostic and therapeutic events in the fields of medicine and specifically in oncology. ${ }^{10-11}$ Shockingly, the oral potentially malignant disorder (PMDs) and cancer are spreading like an epidemic. Oral PMDs occurs much higher than oral cancer and these lesions have been predicted to be a useful clinical marker for the detection of oral cancer. ${ }^{12}$ Findings of types of areca nut consumption, total duration, quantity, duration of chewing, and areca nut chewing during sleep are consistent to previous studies. ${ }^{13-14}$

$\mathrm{Zn}$ is physiologically and biologically essential for the normal development, growth and function in mammals. ${ }^{15} \mathrm{Zn}$ is basically involved as a cofactor in carbonic anhydrase, carboxy peptidase, leucine peptidase and SOD. $\mathrm{Zn}$ is also an essential component for regulating cell cycle and cell division and is also an essential ion needed for the activation of DNA polymerase enzyme. ${ }^{16}$ In the present study, serum copper and Zinc levels were low in control group A compared to OSMF group B which showed raised serum Zn levels. In the present study, serum $\mathrm{Zn}$, mean $\pm S D$ in controls (Group II) and cases (Group I OSMF) was noted as $68.06 \pm 17.10$ and $94.20 \pm 15.11$ $\mu \mathrm{g} / \mathrm{dl}$ respectively $(\mathrm{t}=6.27, \mathrm{p}=0.001)$.

The findings of serum $\mathrm{Zn}$ levels of present study are in keeping with previous studies. ${ }^{17-18}$ They reported raised salivary $\mathrm{Zn}$ may provide protective role against free radicals because $Z n$ is antioxidant as it is needed for enzymes biological activity, hence its levels are increased once oxidative stress is increased as occurs by areca nut chewing.

\section{CONCLUSION}

Current study confirms that, patient who had habit of areca nut chewing showed increased amounts of trace elements (serum copper and zinc). Research reports revealed that, Copper and Zinc could contribute to the pathogenesis of OSMF complications. Role of copper and zinc has been documented and confirmed by the present study. The present study concludes that increased serum trace element levels has significant role in the development and pathogenesis OSMF patients.

Copyright $(14$ Dec, 2020.

\section{REFERENCES}

1. Kumar, K., \& Chettiankandy, T. (2020). Evaluation of factors responsible for the occurrence of oral submucous fibrosis in patients referred to darbhanga medical college and hospital. International Journal of Medical and Biomedical Studies, 4(2). https://doi. org/10.32553/ijmbs.v4i2.976.

2. Sunali Khanna. (2008)Immunological and Biochemical Markers in Oral Carcinogenesis: The Public Health Perspective. pp 418-422.

3. Syed Mumtaz Ali, Rehan Qureshi, Syed Jamal(2011) Prevalence of Oral submucous Fibrosis and use of tobacco and related products amongst school going males. Pakistan Oral \& Journal Vol 31,No.2.pp 384-387.

4. Manasi Ankolekar Kode, Freny Rashmiraj Karjodkar. Estimation of the serum and the salivary trace elements in OSMF patients. Journal of clinical and diagnostic research: JCDR 7.6 (2013): 1215.

5. C.R Trivedy, G. Craig, Warnakulasuriya. The oral health consequences of chewing areca nut. Addiction biology 7.1 (2002): 115-125.

6. Sunali $S$ Khanna, Freny $R$ Karjodkar. Circulating immune complexes and trace elements (Copper, Iron and Selenium) as markers in oral precancer and cancer: a randomised, controlled clinical trial. Head \& Face Medicine 2.1 (2006): 1-10.

7. Jythi Tadakamadla, Santhosh Kumar, Mamatha GP, Evaluation of serum copper and iron levels among oral sub mucous fibrosis patients. pp 870-873.

8. Silva MP, Soave DF, Ribeiro-Silva A, Poletti ME. Trace elements as tumor biomarkers and prognostic factors in breast cancer: A study through energy dispersive x-ray fluorescence. BMC Res Notes 2012; 5:194.

9. Ayinampudi BK, Narsimhan M. Salivary copper and zinc levels in oral pre-malignant and malignant lesions. J Oral Maxillofac Pathol 2012; 16:178-82.

10. Schwartz MK. Role of trace elements in cancer. Cancer Res 1975;35:3481-7

11. Tiwari R, David CM, Mahesh DR, Sambargi U, Rashmi $\mathrm{KJ}$, Benakanal P. Assessment of serum copper, iron and immune complexes in potentially malignant disorders and oral cancer. Braz. Oral Res 2016; 30(1):e101 1 . 
12. Okade AR, Hallikeri KS, Trivedi DJ. Salivary estimation of copper, iron, zinc and manganese in oral submucous fibrosis patients: A case-control study. Clin Cancer Investig J 2015; 4:302-6.

13. Shetty SR, Babu S, Kumari S, Shetty P, Hegde S, Karikal A. Status of trace elements in saliva of oral precancer and oral cancer patients. J Can Res Ther $2015 ; 11: 146-9$.

14. Chitra S, Balasubramaniam M, Hazra M. Effect of a-tocopherol on salivary reactive oxygen species and trace elements in oral submucous fibrosis. Ann Clin Biochem 2012; 49: 262-265.
15. Kima CU, Songc HJ, Avvarud BS, Grunera SM, Parkc SY, McKennad R. Tracking solvent and protein movement during $\mathbf{C O} 2$ release in carbonic anhydrase II crystals. Proceed Nat Acad Sci 2016; 113 (19): 5257-5262.

16. Kumagai T, Abe K, Yoshida W, Ikebukuro K. DNA Detection Technology Using Zinc Finger Protein. J Microb Biochem Technol 2015; 7:278-281.

17. Ayinampudi BK, Narsimhan M. Salivary copper and zinc levels in oral pre-malignant and malignant lesions. J Oral Maxillofac Pathol 2012; 16:178-82

18. Desai VD, Kumar MV, Mathi RJ, Gaurav I, Sharma R. Molecular analysis of trace elements in oral submucous fibrosis and future perspectives. Univers Res J Dent 2014; 4:26-35.

\begin{tabular}{|c|c|c|c|}
\hline \multicolumn{4}{|c|}{ AUTHORSHIP AND CONTRIBUTION DECLARATION } \\
\hline Sr. \# & Author(s) Full Name & Contribution to the paper & Author(s) Signature \\
\hline 1 & Waqas Iqbal & Data collection. & \\
\hline 2 & Arhama Surwaich & Manuscript writing. & \\
\hline 3 & Surwaich Ali Channa & Manuscript review. & \\
\hline 4 & Khalid Yousuf & Data analysis. & \\
\hline 5 & Shahzaman Memon & Manuscript writing. & \\
\hline 6 & Shafquat Hussain Khuwaja & Review of literature. & \\
\hline
\end{tabular}

